\title{
The Use of a Three-in-One Practice-Management- Innovation Training Model in the Construction of an Infection Control Team
}

\section{Qifen Min \\ Jianshui Yang \\ Xiaowen Gong}

Department of Nosocomial Infection Management, Changzhou Cancer

Hospital, Changzhou, Jiangsu, 213032,

People's Republic of China
Correspondence: Xiaowen Gong Department of Nosocomial Infection Management, Changzhou Cancer

Hospital, Changzhou, Jiangsu, 213032.

People's Republic of China

Tel +86 I38I50I9920

Fax +86 519-69807240

Email gongxw_dr@l63.com
Objective: This study aims to explore the role of a three-in-one practice, management, and innovation training model (also called as three-in-one practice-management-innovation training model) in the construction of an infection control team.

Methods: This study retrospectively analyzed the position structure, mastery of professional knowledge, and working methods of the full-time and part-time personnel of the Changzhou Cancer Hospital, compared the training content of Jiangsu Hospital Infection Control Center with the actual situation of the hospital, and formulated and implemented a three-in-one practicemanagement-innovation training model. First, the team members were selected for the construction and management of the Hospital Infection Management Department according to the relevant responsibility and management requirements, and their learning and mastery of the basic knowledge and skills concerning infection control were completed based on their professional roles. In line with the regulations of the hospital and department, full-time personnel were ensured of having the opportunity to participate in provincial- and municipal-level academic exchanges and then learn from each other, through collaboration between doctors and nurses, how to exercise basic management skills. At the same time, a fair competitive incentive mechanism was established through the three-level network of the hospital infection committee, the hospital infection management department, and nosocomial infection management department to implement innovative projectbased management and cultivate an awareness of hospital infection control in all employees.

Results: The professional structure of the full-time infection control personnel has been optimized, the awareness of the infection control team concerning active participation in practice has gradually increased, and infection control management and innovation has been significantly improved.

Conclusion: After the selection of an infection control management team and the delivery of well-planned training, the quality of infection control management has improved.

Keywords: hospital infection, infection control team, three-in-one training model

\section{Introduction}

Hospital infection management in China came about later than it did in more developed countries, ${ }^{1}$ and, to date, there has been no literature report on training models of hospital infection control teams in China. With the rapid development of modern medicine, health care work has become more and more complicated, ${ }^{2}$ placing higher demands on infection control teams. Since the quality of the infection control team directly affects medical safety and quality, ${ }^{3}$ the construction of elite infection control teams within a short space of time to prevent the social and economic losses of hospital infections has become a challenge. ${ }^{4}$ The aim of this 
study is to improve the basic knowledge, innovative practice, and scientific research literacy of the Changzhou Cancer Hospital's hospital infection control team and promote and develop management work related to hospital infection. To this end, this study analyzed the situation of the hospital's hospital infection control team since 2016 and borrowed from the management experience of other hospitals at the same or a superior level and combined this with the current development of the hospital and its medical disciplines in order to create a three-in-one practicemanagement-innovation training model. The aim of this model is to strengthen the infection control team through the use of standardized selection and training mechanisms and project-based management methods, thereby improving the quality of hospital infection management at our hospital. This paper discusses the three-in-one practicemanagement-innovation training model in the construction of an infection control team to increase the awareness of the infection control team.

\section{Data and Methods Data}

In 2016, there were three full-time infection control personnel, two with a nursing major and one with a public health major. Two of them were bachelor degree holders and one of them a junior college degree holder. Their positions were at junior, intermediate, and sub-senior levels, their ages were 30,44 , and 51 years old, and their working experience in the hospital was 6,25 , and 32 years, respectively.

It was clear that there was a wide range of issues that required attention. Firstly, as the full-time personnel were not welcomed by clinical medical personnel, and their income level was low, job burnout was a common occurrence. In addition, part-time infection control personnel, designated by the department directors or head nurses, were often transferred to other departments according to their needs, thus the mobility of such personnel was very high. Moreover, a systematic and standardized training and evaluation system was also lacking. Professional infection management personnel only participated in theory training for two to three days, and after passing the examination, they were issued with a certificate of employment, but there were no opportunities for further training at higherlevel hospitals and very few opportunities to participate in provincial and municipal training. It is clear that the main way for part-time personnel to obtain relevant knowledge and professional skills is through instruction from fulltime personnel and participation in training courses, but this requires systematic and standardized training practice, and due to the rapid update of knowledge in the subject of infection management, full-time personnel are also required to continuously learn and improve their own capabilities. All these problems needed to be addressed.

\section{Methods}

\section{Taking into Consideration a Variety of Professional Backgrounds}

The selection of full-time personnel is now conducted according to the requirements of the hospital infection management department, and a two-year recruitment and training plan has been formulated. A hospital infection control team needs full-time personnel with a variety of professional backgrounds, including clinical doctors, nursing staff, microbiological testing personnel, public health practitioners, and other professionals with academic qualifications as well as part-time infection control staff. The high quality of these members of staff and their awareness of the importance of department infection management are prerequisites for good hospital infection management.

\section{Systematic Training}

(1) Full-time personnel: an 18-month clinical rotation has been implemented for the full-time personnel, in line with Training Guidelines for Hospital Infection Management Personnel WS/T 525-2016 $6^{5}$ and the actual requirements of the hospital. The tasks include: (a) following the ward rounds every morning; (b) evaluating case monitoring, device-related infections, bacterial resistance, clinical antibacterial drug use, etc., according to the type of disease and the infection characteristics of the case; (c) identifying unreasonable empirical drug use and specimens not taken before use; (d) performing a differential diagnosis of infection cases; (e) discussing reports and other situations that arise; (f) narrowing the distance with front-line medical staff; (g) mastering various monitoring methods; and (h) generally improving professional levels, and consolidating the foundation of infection control management. At the same time, full-time personnel are now able to obtain provinciallevel qualifications, participate in the training of key departments throughout the process, conduct self-study of the key standards of the ten key departments, and a full-time hospital infection instructor has been appointed to explain every management rule of the ten key departments. After a theory test is passed, a one-to-two-week on-site training 
course is held aimed at strengthening communication between medical staff and ensuring proficiency in key department management skills. Full-time personnel who have undergone clinical rotation and training in key departments can then apply for short-term advanced studies in higher-level hospitals to gain advanced infection control management experience and obtain qualifications. The fulltime staff who return to their posts after the advanced studies course then undertake a teaching task of eight class hours or more. Full-time staff who have worked in the hospital for six years participate in the Clinical Training Program for Hospital Infection Control Doctors in Jiangsu Province and obtain a certificate of completion.

(2) The infection control team is now trained in the following manner: (a) all team members participate in management pre-job training and obtain in-hospital qualifications; (b) expert teacher training is arranged, covering teacher dress code, introductory classes, class control, etc.; (c) team members give instruction programs following various training course outlines provided by Jiangsu Province; (d) the hospital infection department delivers a three-day management training course to part-time doctors and nurses, with the training content referring to the construction requirements of the hospital infection management department, and everyone must pass the assessment; and (e) two part-time members of staff from general departments are selected every year and sent on courses concerning the theoretical and operational training of infection control posts at the municipal level, and two infection control team members from key departments participate in similar courses at the provincial level and obtain qualifications.

\section{Project-Based Continuing Education Management}

The continuing education of personnel is now managed in the following way: (1) A study plan is developed for their participation in external activities, and infection control team members take part in academic conferences and continuously update their infection control knowledge; (2) Data concerning infection cases is gathered continuously. Since the launch of the Infection Cases Collection Activity in Jiangsu Province in 2018, infection control doctors have examined cases related to the respiratory and digestive systems, the urinary tract, the skin and soft tissues, the central nervous system, the eyes, ears, nose, and throat, surgical sites, sepsis, fever, and hospital infections, and other related diseases. Typical cases are selected and the treatment plan (antibacterial drugs) analyzed and discussed on a regular basis, and the proceedings are published in the Hospital Infection Control Bulletin every quarter for the whole hospital to review; (3) There are antibacterial drug improvement classes. Using the Infection Control Physician Clinical Training Project in the WeChat public account of the Home of Infection Control as a learning platform, doctors from the whole hospital participate in the project once a week. The 17 sessions of video learning are supervised and assessed by the infection control doctors on each ward. The hospital infection control department uses a questionnaire for examination and summary every week; (4) There is a monthly activity to improve the management ability of the infection control team, and they also take part in the Infection Control Team Management Ability Improvement Month activity in October every year. The specific direction of improvement is determined according to the actual situation of the hospital, and a series of training activities are organized to improve the management level of the whole hospital in a uniform manner; (5) There is an infection control assembly in November each year, when representatives from all hospital departments participate in emergency response plan drills for hospital infection outbreaks and medical waste leakage. The aim is for participants to master the disposal process and improve their ability to respond to emergencies; in response to the sudden outbreak of COVID-19, a hospital epidemic prevention and control leading group was immediately set up to formulate prevention and control plans and organize professional training and assessments for the whole hospital, so everyone could master the accurate usage, donning, and removal of protective equipment and realize the objective of infection control; (6) The Infection Control disciplines are in constant development, with members of the infection control team being actively encouraged to publish papers and apply for projects related to infection control. Staff are also encouraged to participate in national, provincial, and municipal academic conferences and poster presentations and to run provincial and municipal continuing education projects (see Figure 1).

\section{Results}

\section{A Comparison of Full-Time Infection Control Personnel in 2016 and 2020}

After a screening of their professional and academic qualifications, as of 2020, the three full-time personnel include an infection control epidemiologist, an examiner, and a nurse, showing that the professional structure of the fulltime personnel has been optimized. There is one master's degree holder and two bachelor's degree holders, showing that the education level of the team has been improved, and a talent echelon has been formed. At present, all of 

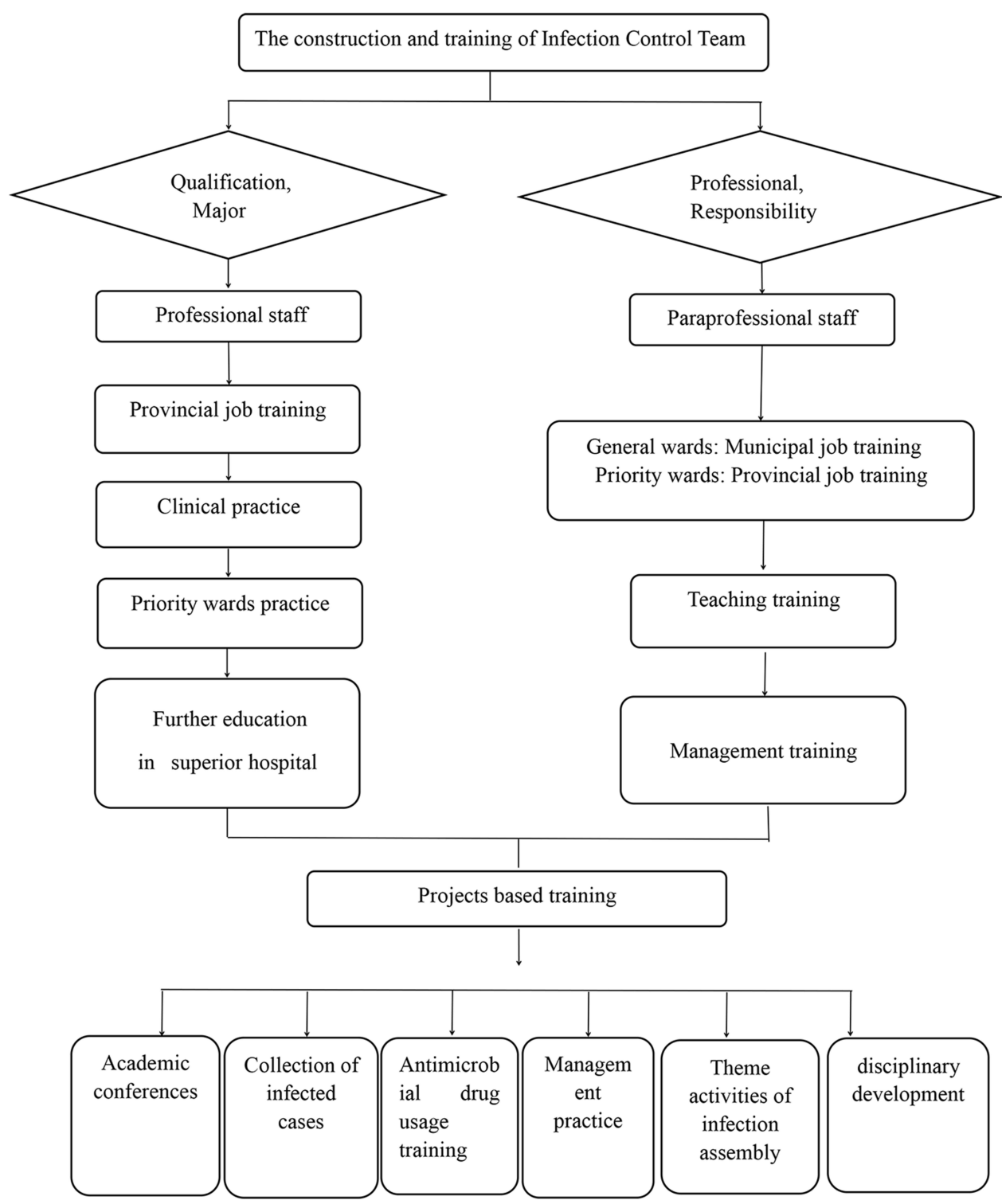

Figure I Application process of the Three-in-One "Practice, Management and Innovation" Training Model in the Construction of Infection Control Team.

them have obtained the provincial qualification, and one of them has obtained the certificate of completion of the Clinical Research and Training Program for Infection Control Doctors in Jiangsu Province. They have all undergone comprehensive systematic professional training at Nanjing Drum Tower Hospital and Jiangsu Provincial People's Hospital (see Table 1).

\section{The Awareness Rate of the Part-Time Personnel Concerning Hospital Infection-Related Knowledge}

The hospital currently has 12 part-time personnel qualified at municipal level and 16 qualified at provincial level. Thus, after systematic training, the awareness rate of the part-time personnel with respect to hospital infectionrelated knowledge has increased significantly with a p-value under 0.001 (see Table 2).

\section{Awarded or Published Papers in the 5 Years After the Implementation of the Training}

After a series of projects, the management practice skills and scientific research quality of the infection control team have gradually improved, and as a reflection of this achievement our hospital won the Excellent Organization Award in the first Jiangsu Province Infection Case Collection Activity in 2018. Three doctors have been invited to participate in the Provincial Infection Control Physician Training Program to discuss 
Table I Comparison of Full-Time Infection Control Personnel in 2016 and 2020

\begin{tabular}{|l|c|c|c|c|c|c|}
\hline Year & Sex & Age & Degree & Specialty & Title & Working Years \\
\hline 2015 & Female & 51 & Diploma & Nursing & Intermediate & 32 \\
& Female & 44 & Bachelor & Nursing & $\begin{array}{c}\text { Deputy senior } \\
\text { Intermediate }\end{array}$ & 6 \\
& Male & 30 & Bachelor & Preventive Medicine & Senior & 30 \\
& Female & 49 & Bachelor & Nursing & Intermediate & 11 \\
& Female & 35 & Bachelor & Laboratory Medicine & Primary & 3 \\
& Male & 29 & Master & Epidemiology & Prim \\
& & &
\end{tabular}

Table 2 Awareness Rate of the Part-Time Personnel on Hospital Infection Related Knowledge

\begin{tabular}{|c|c|c|c|c|c|c|c|}
\hline \multirow[t]{2}{*}{ Hospital Infection Related Knowledge } & \multicolumn{3}{|c|}{2015} & \multicolumn{3}{|c|}{2020} & \multirow[t]{2}{*}{$P^{\mathbf{a}}$} \\
\hline & $\begin{array}{l}\text { Fully } \\
\text { Aware }\end{array}$ & $\begin{array}{l}\text { Partially } \\
\text { Aware }\end{array}$ & Unaware & $\begin{array}{l}\text { Fully } \\
\text { Aware }\end{array}$ & $\begin{array}{l}\text { Partially } \\
\text { Aware }\end{array}$ & Unaware & \\
\hline $\begin{array}{l}\text { Hand hygiene effect monitoring and } 5 \text { indications for } \\
\text { hand washing }\end{array}$ & 35 & 15 & 0 & 50 & 8 & 0 & $<0.001$ \\
\hline Sharp injury treatment and reporting & 30 & 15 & 5 & 42 & 16 & 0 & $<0.001$ \\
\hline $\begin{array}{l}\text { Standard preventive knowledge and use of protective } \\
\text { equipment }\end{array}$ & 28 & 13 & 9 & 45 & 13 & 0 & $<0.001$ \\
\hline Medical waste disposal & 25 & 15 & 10 & 48 & 10 & 0 & $<0.001$ \\
\hline $\begin{array}{l}\text { Specimen collection and environmental hygiene testing } \\
\text { requirements }\end{array}$ & 20 & 22 & 8 & 30 & 27 & I & $<0.001$ \\
\hline $\begin{array}{l}\text { Hospital infection risk factors and prevention of } \\
\text { catheter-related infections }\end{array}$ & 26 & 15 & 9 & 36 & 22 & 0 & $<0.001$ \\
\hline Use methods and precautions of common disinfectants & 32 & 10 & 8 & 35 & 22 & $\mathrm{I}$ & $<0.001$ \\
\hline $\begin{array}{l}\text { Detection and prevention and control measures of } \\
\text { multi-drug resistant bacteria }\end{array}$ & 34 & 13 & 3 & 55 & 3 & 0 & $<0.001$ \\
\hline $\begin{array}{l}\text { Comprehensive surveillance and targeted surveillance } \\
\text { of hospital infection }\end{array}$ & 23 & 21 & 6 & 26 & 30 & 2 & $<0.001$ \\
\hline $\begin{array}{l}\text { Disinfection and sterilization knowledge and aseptic } \\
\text { technology }\end{array}$ & 24 & 15 & II & 42 & 16 & 0 & $<0.001$ \\
\hline
\end{tabular}

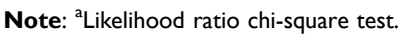

infection cases, and within five years, before and after the implementation of the training plan, there has been an increase in the number of papers that have been published and awards received (see Table 3).

\section{Discussion}

With the aging of the full-time infection control personnel, the infection management department came to be regarded as the hospital's "elderly care department". Some clinical medical staff felt that the infection control department was always pointing fingers at clinical workers and deducting points or money from the clinical staff, so they did not like the infection control department. The development of the infection control department was therefore greatly hindered by the lack of attention and understanding from other staff members, the low income of the full-time personnel, their lack of self-worth, and the unstable team structure, ${ }^{6-8}$ which in turn caused hidden dangers to medical safety. The high mobility of part-time infection control nurses was also a serious issue in the structure of the infection control team. ${ }^{9,10}$ Therefore, candidates for the infection control team were selected from those who displayed a sense of responsibility, strong professional ability, great management potential, good psychological and 
Table 3 Awarded or Published Papers in the 5 Years After the Implementation of the Training

\begin{tabular}{|l|c|c|}
\hline & $\begin{array}{c}20 \text { II- } \\
2015\end{array}$ & $\begin{array}{c}2016- \\
2020\end{array}$ \\
\hline $\begin{array}{l}\text { Number of awards for papers in hospital } \\
\text { infection management annual conferences }\end{array}$ & 0 & 5 \\
\hline Published papers related to hospital infections & 0 & 2 \\
SCl & 0 & 8 \\
Chinese core journals & 0 & 16 \\
Non-core journals & 0 \\
\hline
\end{tabular}

communication skills, and intermediate and above professional qualifications. The selection criteria laid a good human resource foundation for the three-in-one practicemanagement-innovation training model.

It was important to build an infection control team management collaboration mechanism, which recognizes that personal development is inseparable from teamwork, in-depth practice and research, and the cultivation of innovative thinking. ${ }^{11,12}$ Therefore, it has been essential to allow each team member to pursue their own professional development while gaining a basic knowledge of infection control in combination with exercising basic management skills, in a way that fosters collaboration between doctors and nurses. In so doing, the hospital has been successful in building a unified infection control management system. ${ }^{13}$ At the same time, innovative project-based management in continuing education has been adopted, which has ensured that full-time personnel have the opportunity to participate in provincial and municipal annual meetings every year, and part-time personnel can participate in corresponding provincial and municipal annual meetings and learn from their peers at the hospital. Continuing education is also implemented on the Home of Infection Control platform, so staff can bring themselves up-to-date with the latest knowledge about hospital infection as well as communicating with their peers anytime and anywhere. Meanwhile, a competitive incentive mechanism has been introduced to enhance their learning ability ${ }^{14}$ and cultivate their sense of participation as a hospital employee through a three-level network working model of infection control at both the hospital and departmental level. ${ }^{15-17}$ So, for example, the selection of advanced infection management individuals and departments in Changzhou Hospital is carried out every three years to increase the sense of personal value of both full-time and part-time infection control personnel.
To cultivate innovative thinking, medical personnel of all ages are encouraged to write papers and learn from each other, so their innovative management ability can be continuously enhanced. In the past five years, the infection control team has won a series of awards at the provincial level. At the same time, the hospital has been offering double rewards, which has greatly encouraged a sense of honor and pride amongst team members, strengthened the advantages of teamwork collaboration, noticeably improved the management ability of the team, and had a great impact within the hospital. Effective management practice is a key to improving the hospital's overall infection control management ability, and stability maintenance is an effective lever for the team to maintain its vitality. Therefore, it is important to win support from the leaders of infection control management work to improve the working environment and working conditions of full-time personnel, add performance-based awards, and further clarify tasks and responsibilities. A combination of meetings and individual communications are used to strengthen the publicity and education of hospital infection management, ${ }^{18}$ so that clinicians can recognize the significance of this work, and the infection control personnel can enjoy increased professional pride. A management performance incentive mechanism and management rewards and punishment rules for part-time infection control personnel have been set up, and review results are summarized every quarter to announce the details of rewards and punishments. In addition, a project management competition is held jointly with the hospital labor union every year to create a positive sense of team working so that other staff are more willing to collaborate with the part-time personnel in department infection control management. It is also aimed at motivating both the full-time and part-time infection control personnel, attracting a younger workforce to this field, promoting the continuous and healthy development of hospital infection management in our hospital, and, overall, contributing to medical safety.

However, there is still a gap between the full-time infection control personnel structure of this hospital and domestic hospitals at the same level. ${ }^{19,20}$ Limited by the size of the hospital, it is difficult to apply for additional staff, and there is still a lack of personnel with a clinical background. After the second phase of the hospital expansion program is completed, it is hoped that it will be possible to improve on the number and structure of the full-time staff dedicated to infection control management. 


\section{Ethics Approval and Consent to Participate}

The study was conducted in accordance with the Declaration of Helsinki (as was revised in 2013). The study was approved by Ethics Committee of the Changzhou Cancer Hospital. All participants signed a document of informed consent.

\section{Acknowledgments}

We are particularly grateful to all the people who have given us help on our article.

\section{Funding}

There is no funding to report.

\section{Disclosure}

The authors declare that they have no conflicts of interest for this work.

\section{References}

1. Alvim ALS, Couto BR, Gazzinelli A. Quality of the hospital infection control programs: an integrative review. Rev Gaucha Enferm. 2020;41: e20190360. doi:10.1590/1983-1447.2020.20190360

2. Henman LJ, Corrigan R, Carrico R, Suh KN. Identifying changes in the role of the infection preventionist through the 2014 practice analysis study conducted by the Certification Board of Infection Control and Epidemiology, Inc. Am J Infect Control. 2015;43(7):664-668.

3. Bubb TN, Billings C, Berriel-Cass D, et al. APIC professional and practice standards. Am J Infect Control. 2016;44(7):745-749. doi:10.1016/j.ajic.2016.02.004

4. Giroti ALB, Ferreira AM, Rigotti MA, Sousa ÁFL, Frota OP, Andrade D. Hospital infection control programs: assessment of process and structure indicators. Programas de Controle de Infecção Hospitalar: avaliação de indicadores de estrutura e processo. Rev Esc Enferm USP. 2018;52:e03364. doi:10.1590/s1980-220x2017039903364

5. Wu HA, Huang X, Li LY. Guideline for professional training about managing of health-care associated infections. Chin J Infect Control. 2017;16(01):94-97.

6. Lo Giudice D, Trimarchi G, La Fauci V, Squeri R, Calimeri S. Hospital infection control and behaviour of operating room staff. Cent Eur J Public Health. 2019;27(4):292-295. doi:10.21101/cejph.a4932

7. Kalil AC, Metersky ML, Klompas M, et al. Management of adults with hospital-acquired and ventilator-associated pneumonia: 2016 clinical practice guidelines by the Infectious Diseases Society of America and the American Thoracic Society. Clin Infect Dis. 2016;63(5):e61-e111.
8. Zhang PJ, Tang LL, Qian LH, et al. Current status of job burnout and effort-reward imbalance among full-time healthcare-associated infection management staff in Wuhu City. Chin J Infect Control. 2019;18 (12):1159-1164

9. Hessels AJ, Kelly AM, Chen L, Cohen B, Zachariah P, Larson EL. Impact of infectious exposures and outbreaks on nurse and infection preventionist workload. Am J Infect Control. 2019;47(6):623-627. doi:10.1016/j.ajic.2019.02.007

10. Plemmons MM, Marcenaro J, Oermann MH, Thompson J, Vacchiano CA. Improving infection control practices of nurse anesthetists in the anesthesia workspace. Am J Infect Control. 2019;47(5):551-557. doi:10.1016/j.ajic.2018.12.009

11. Liu W, Tian Y, Zheng Z, Cao Q. Survey of hospital infection management staff in the Inner Mongolia Autonomous Region. Zhonghua Yi Xue Za Zhi. 2015;95(40):3302-3304.

12. Yoshida H, Matsuda S, Aratani T, et al. Collaboration with an infection control team promoted appropriate antibiotic use for third molar extraction at a Japanese hospital. J Infect Chemother. 2020;26 (6):531-534. doi:10.1016/j.jiac.2020.01.003

13. Troughton R, Mariano V, Campbell A, Hettiaratchy S, Holmes A, Birgand G. Understanding determinants of infection control practices in surgery: the role of shared ownership and team hierarchy. Antimicrob Resist Infect Control. 2019;8:116. doi:10.1186/s13756019-0565-8

14. Boyer PH, Deboscker S, Hernandez C, et al. An undiagnosed index case leading to a nosocomial scabies outbreak: how mass single-dose ivermectin treatment can help control a nosocomial epidemic. Infect Control Hosp Epidemiol. 2018;39(5):631-632. doi:10.1017/ ice.2018.31

15. Suleyman G, Alangaden GJ. Nosocomial fungal infections: epidemiology, infection control, and prevention. Infect Dis Clin North Am. 2016;30(4):1023-1052. doi:10.1016/j.idc.2016.07.008

16. Baghdadi I, Bengriche L, Immessaoudene F, et al. Rôle du CLIN lors d'une infection nosocomiale dans un hôpital d'Alger Est [Nosocomial infection control committee's role in a nosocomial infection at an East Algiers hospital]. Ann Biol Clin (Paris). 2020;78(1):74-78.

17. Fernández-Gracia J, Onnela JP, Barnett ML, Eguíluz VM, Christakis NA. Influence of a patient transfer network of US inpatient facilities on the incidence of nosocomial infections. Sci Rep. 2017;7 (1):2930. doi:10.1038/s41598-017-02245-7

18. Quraishi MN, Widlak M, Bhala N, et al. Systematic review with meta-analysis: the efficacy of faecal microbiota transplantation for the treatment of recurrent and refractory Clostridium difficile infection. Aliment Pharmacol Ther. 2017;46(5):479-493. doi:10.1111/apt.14201

19. Alscher MD, Erley C, Kuhlmann MK. Acute renal failure of nosocomial origin. Dtsch Arztebl Int. 2019;116(9):149-158.

20. Yuan XF, Kong FJ. Status of hospital infection control department and staff in 40 hospital in Changsha City. World Latest Med Inform. 2019;19(20):242-243.
Risk Management and Healthcare Policy is an international, peerreviewed, open access journal focusing on all aspects of public health, policy, and preventative measures to promote good health and improve morbidity and mortality in the population. The journa welcomes submitted papers covering original research, basic science, clinical \& epidemiological studies, reviews and evaluations, guidelines, expert opinion and commentary, case reports and extended reports. The manuscript management system is completely online and includes a very quick and fair peer-review system, which is all easy to use. Visit http://www.dovepress.com/testimonials.php to read real quotes from published authors. 